\title{
Sosyal Medyanın En Aktif Markaları: Diyalojik İletişim Teorisi Bağlamında Facebook Üzerine Bir Araştırma
}

Cudi Kaan Okmeydan (Arş. Gör. Dr.)

Yaşar Üniversitesi İletişim Fakültesi

cudi.okmeydan@yasar.edu.tr

Başvuru Tarihi: 18.03.2020

Yayına Kabul Tarihi: 20.06.2020

Yayınlanma Tarihi: 24.07.2020

https://doi.org/10.17680/erciyesiletisim.705999

\section{Öz}

Bu çalışmanın amacı, Boom Social'ın Eylül 2019 Raporunda açıklandığı üzere Facebook'u en aktif kullanan Netflix, Madame Coco, THY, Ziraat Bankası ve Mutlu Akü olmak üzere ilk beş markanın resmî Facebook sayfalarında hangi diyalojik ilkelerin ortaya çıktığını ve bunun sonucunda markaların takipçileri ile geliştirdiği iletişim bağlamını saptamaktır. İlgili markaların resmî Facebook sayfaları Kent ve Taylor'ın (1998) Diyalojik İletişim İlkeleri bağlamında içerik analizi yöntemi ile incelenmiştir. İçerik analizi modelinin oluşturulmasında Waters vd. (2011) ile Yağmurlu'nun (2013) çalışmalarından uyarlama yapılmıştır. Kent ve Taylor'ın Diyalojik İletişim Teorisi; 'Diyalojik Döngü', 'Enformasyon Kullanışlılığı', 'Yeniden Ziyaret Sağlama', 'Arayüzün Kullanışlılığı' ve 'Ziyaretçilerin Korunması' olarak beş ilkeden oluşmaktadır. Araştırma sürecinde beş diyalojik ilkeden dördüncüsü olan 'Arayüzün Kullanıșlılığı', Facebook'un standart arayüze sahip olması nedeniyle değerlendirme dişı bırakılmıștır. Araştırma sonucunda Kent ve Taylor'ın beş diyalojik ilkesinden ilki olan diyalojik döngünün, üç markanın Facebook sayfasında ortaya çıktığı görülmüş ancak diğer iki markanın sayfasında tek yönlü iletişimin hâkim olduğu saptanmıștır. Değerlendirmeye dahil edilen diğer diyalojik ilkeler olan 'Enformasyon Kullanışlılığı', 'Yeniden Ziyaret Sağlama' ve 'Ziyaretçilerin Korunması' ilkeleri incelendiğinde araştırmaya konu olan tüm markaların Facebook sayfalarında benzer sonuçların ortaya çıktığı görülmüştür.

Anahtar Kelimeler: Halkla İlişkiler, Web, Sosyal Medya, İletişim, Diyalojik İletişim. 


\title{
The Most Active Brands of the Social Media: A Research on Facebook within the Context of Dialogical Communication Theory
}

\author{
Cudi Kaan Okmeydan (Res. Asst. Ph.D.) \\ Yaşar University Faculty of Communication \\ cudi.okmeydan@yasar.edu.tr
}

Date Received: 18.03.2020

Date Accepted: 20.06 .2020

Date Published: 24.07.2020

https://doi.org/10.17680/erciyesiletisim.705999

\begin{abstract}
The purpose of this study is to determine the dialogical principles that occur on the Facebook pages of Netflix, Madame Coco, THY, Ziraat Bankası, and Mutlu Akü, which are the top five brands using Facebook the most actively according to the September 2019 report of the Boom Social; and to find out their communication context developed with their followers concerning those principles. The official Facebook pages of the mentioned above have been reviewed by the content analysis method within the context of Dialogic Communication Principles of Kent and Taylor (1998). In the establishment of the content analysis method, adaptations have been made from the studies of Waters et al. (2011) and Yağmurlu (2013). The Dialogic Communication Theory consists of five principles which are: "Dialogic Loop", "Usefulness of Information", "Generation of Return Visits", "Ease of Interface" and "Conservation of Visitors". The fourth one of the five dialogic principles, that is, "Ease of Interface", is not included in the evaluation during the research stage because Facebook has a standard interface. According to the findings of the research, the dialogic loop which is the first one of the five dialogic principles, are observed on the Facebook pages of the three brands but it is seen that unilateral communication is predominant on the pages of the two other brands. When the other dialogic principles, "Usefulness of Information", "Generation of Return Visits", and "Conservation of Visitors" are examined, it is seen that similar results occur on the Facebook pages of all the brands included in the research.
\end{abstract}

Keywords: Public Relations, Web, Social Media, Communication, Dialogical Communication. 


\section{Giriş}

Sosyal medya olarak adlandırılan Web 2.0 teknolojisinin kullanıcı içerikli ve interaktif yapısı markalara önemli fırsatlar sunmaktadır. Çeşitli pazarlama süreçlerinin yanı sıra markalar, sosyal medya aracılığıyla hedef kitleleri ile etkileşim kurabilme ve ilişki geliştirme olanağı yakalamaktadır. Bununla birlikte günümüz tüketicileri ilgilendikleri veya müşterisi oldukları markalara kurumsal web siteleri yerine resmî sosyal medya hesapları üzerinden ulaşma eğilimindedir. Bu durum, markalar açısından etkin bir sosyal medya yönetimini zorunlu kılmaktadır.

Bu çalışma Boom Social'ın Eylül 2019 Raporuna göre Facebook'u en aktif kullanan markaların ilk beșine odaklanmaktadır. Söz konusu beș markanın resmî Facebook sayfaları Kent ve Taylor'ın Diyalojik İletişim İlkeleri bağlamında içerik analizi yöntemi ile incelenmiştir. Diyalojik Teori, Kent ve Taylor (1998) tarafından web sitelerinin ilişki kurma kapasitelerini ölçmek amacıyla geliştirilmiştir. Teori, internet teknolojileri üzerinden kurum ve hedef kitleleri arasında kurulan diyalog ve ilişkinin, kaynak ve alıcıya sağlayacağı yarar üzerine şekillenmektedir (Değerli, 2016, s. 66). Diyalojik İletişim Teorisi, beș diyalojik ilkeye dayanmaktadır. Bunlardan ilki ve en önemli olarak kabul edilen ilke 'Diyalojik Döngüdür'. Diyalojik döngü, kurumun iletişime açık olup olmadığını belirlemekte, hedef kitleleri ile kurum arasındaki geri bildirim döngüsünü ve oluşan diyalogları açıklamaktadır(Kent ve Taylor, 1998, s. 326-327). Diğer ilkeler ise faydalı içerik sunulmasını ifade eden 'Enformasyon Kullanışlılığı', web sitesine sık ziyareti teşvik eden 'yeniden ziyaret sağlama', web sitesinin kullanım kolaylığını ifade eden 'Arayüzün Kullanışlılı̆̆ı' ve son olarak web sitesinin kaliteli bir deneyim sunmasını ifade eden 'Ziyaretçilerin Korunması' ilkesinden oluşmaktadır.

Günümüzde Kent ve Taylor'ın Diyalojik İletişim Teorisi, sosyal medya araştırmalarına da uyarlanmaktadır. Ancak literatür taraması yapıldığında Diyalojik İletişim Teorisi bağlamında sosyal medya üzerine gerçekleștirilen çalışmaların hâlâ sınırlı sayıda olduğu görülmüştür. Dolayısıyla bu çalışma, alanda tespit edilen bu eksikliği doldurmak ve alana katkı sağlamak amacıyla hazırlanmıştır. Bu nedenle çalışma, Diyalojik İletişim Teorisi bağlamında beș markanın resmî Facebook sayfaları üzerine odaklanmaktadır. Çalıșmanın amacı, araștırmaya konu olan markaların Facebook sayfalarında hangi diyalojik ilkelerin ortaya çıtığını belirlemek ve teori bağlamında sosyal medya üzerinden en ideal marka iletişimini açlklayarak literatürde var olan bir eksikliği gidermektir. Bu nedenle çalışmanın amacının literatüre özgün bir katkı sağlayacağı düşünülmektedir.

Araştırma, Boom Social'ın Eylül 2019 raporunda Facebook'u en aktif kullandığı belirtilen markalardan Netflix, Madame Coco, THY, Ziraat Bankası ve Mutlu Akü olmak üzere ilk beş markayı kapsamaktadır. Çalışmanın araştırma modelinin oluşturulmasında Waters vd. (2011) ile Yağmurlu'nun (2013) çalışmalarından yola çıkılarak uyarlamaya gidilmiş ve araştırmanın amacına en uygun model oluşturulmuştur. İlgili çalışmalardaki modellerin uyarlanmasıyla elde edilen bulgular ışığında, Boom Social'ın Eylül 2019 'Social Brands Report' (Sosyal Markalar Raporuna) göre Facebook'u en iyi kullanan markalardan Netflix ve Madame Coco'nun Facebook sayfalarında Kent ve Taylor'ın diyalojik iletişim ilkelerinden ilki olan diyalojik döngünün ortaya çıkmadı̆̆ı saptanmıştır. Ancak listede üçüncü sırada yer alan THY, dördüncü sırada yer alan Ziraat Bankası ve beşinci sırada yer alan Mutlu Akü'nün Facebook sayfalarında marka ile takipçileri arasında oluşan uzun diyaloglar tespit edilmiş ve diyalojik döngü ilkesinin ortaya çıktığı saptanmıştır. 
Diyalojik iletişim ilkelerinin ilki ve en önemlisi olan diyalojik döngünün THY, Ziraat Bankası ve Mutlu Akü'nün Facebook sayfalarında görülmesi, söz konusu markaların iletişime açık olduğunu ve aynı zamanda paylaşılan içeriklerin ortaya çıkardığı etkileşim gücünü de göstermektedir. Bununla birlikte araștırmaya konu olan markaların paylaşım içerikleri incelendiğinde ticari olmayan bilgilendirici içeriklerin paylaşım sayılarının son derece az olduğu izlenmiştir. Bu durum, araştırma kapsamındaki markaların Facebook sayfalarında enformasyon kullanışlılığı ilkesinin söz konusu olmadığını göstermektedir. Buna karşın tüm markaların Facebook sayfalarının son derece güncel olduğu ve ağırlıklı olarak video ve fotoğraf gibi görsel biçimlerde paylaşım yaptıkları gözlemlenmiștir. $\mathrm{Bu}$ bulgu, yeniden ziyaret sağlama ilkesinin tüm markalar tarafından karşılandığını göstermektedir. Dördüncü ilke olan arayüzün kullanışlılı̆̆l ise Facebook'un standart bir arayüze sahip olması nedeniyle değerlendirmeye alınmamıştır. Beşinci ve son ilke olan ziyaretçilerin korunması ise markaların kurumsal web sayfalarından resmî sosyal medya hesaplarına ait link butonları paylaşmaları, benzer şekilde Facebook sayfalarında kurumsal web sitelerinin bağlantı adreslerine yer vermeleri ve iki aylık araştırma sürecinde ortaya çıkan takipçi sayılarındaki artış ile kendini göstermiştir.

Edinilen bulgular neticesinde, Boom Social 2019 Raporuna göre Facebook sayfalarını en aktif kullanan beș markadan ilk ikisinin, sıralamaya tezat olarak diyalojik döngü ilkesini karşılayamadığı saptanmıștır. Bununla birlikte araştırmaya konu olan tüm markaların, enformasyon kullanışlılığı ilkesini karşılayamadıkları ancak yeniden ziyaret sağlama ve ziyaretçilerin korunması ilkelerini ortaya koydukları görülmektedir. Kent ve Taylor'ın diyalojik iletişim ilkeleri bağlamında yapılan bu çalışmada, araştırmaya konu olan markalar arasında fark ortaya çıkaran ilkenin, diyalojik döngü olduğu tespit edilmiştir.

\section{Sosyal Medya ve Web Kavramı}

Sosyal medya, özünde internet kullanıcılarının yer ve zaman sınırı olmadan kendi içeriklerini oluşturup başkalarıyla paylaşabildikleri ve birbirleriyle etkileşim kurabildikleri yeni nesil Web sitelerini ifade etmektedir. Söz konusu kullanıcı içerikli yeni nesil Web siteleri Web 2.0 olarak adlandırılmaktadır. İnternet teknolojilerinin ilk adımı olan kaynak içerikli Web 1.0'daki tek yönlü iletişim, kullanıcı içerikli Web 2.0 teknolojisine geçilmesiyle birlikte yerini çift yönlü iletişime bırakarak etkileşime olanak tanımış ve bu yeni teknoloji, günümüzdeki klasik ifadesi ile sosyal medya adını almıştır (Okmeydan, 2018, s. 145). Bu bağlamda Web 2.0 ve sosyal medya aynı anlamı ifade etmektedir. Web 2.0 kavramı, ilk kez 2004 yılında O’Reilly Media firması tarafından yeni nesil Web teknolojilerini tanımlamak amacıyla kullanılmıştır (Akar, 2011, s. 16). Web 2.0 olarak adlandırılan bu yeni nesil Web 2.0 teknolojisi, Web 1.0'ın aksine internet kullanıcılarını bir grup profesyonelin hazırladığı içeriğe mecbur etmek yerine onlara kendi içeriklerini oluşturma ve yayma olanağı sağlayan interaktif bir platformdur. Günümüzde ise 'anlamsal (semantik) Web' olarak kabul edilen ve Web sözcügünün babası Tim Berners Lee tarafından Web 3.0 olarak adlandırılan (Abdüsselam, vd. 2015, s. 266) yeni nesil Web teknolojisi ile süreç bir adım daha ileriye giderek bireylere gerek web sitelerinde dolaşırken gerekse sosyal medya sitelerindeyken daha kişiselleşmiş bir deneyim sunulmaktadır. Web 3.0, en temel anlatımıyla, web siteleri üzerinden bilgi çıkarımında bulunan, kişiye özel etkili sonuçlar ve öneriler sunan, arama motorları ve kişisel özelliklerin belirli bir veri bankasında toplanarak bilgilerin değerlendirildiği bir yapıyı ifade etmektedir (Demirli ve Kütük, 2016, s. 98). Bu bağlamda günümüzün yeni nesil anlamsal web teknolojileri, Web 2.0'ın sunduğu tüm olanaklara ek olarak arama motorlarında ve sosyal medya aramalarında daha kişisel sonuç, daha kişisel reklam, daha 
kişisel ürün, hizmet ve ilgi alanlarına yönelik içerik önerisinde bulunmaktadır. Tablo 1'de Web 1.0, Web 2.0 ve Web 3.0 teknolojileri, temel özellikleri bakımından karşılaştırmalı olarak özet bir biçimde açıklanmaktadır.

Tablo 1: Web 1.0, Web 2.0 ve Web 3.0 Arasindaki Farklar

\begin{tabular}{|c|c|c|c|}
\hline & Web 1.0 & Web 2.0 & Web 3.0 \\
\hline $\begin{array}{l}\text { Getirdiği } \\
\text { Yenilikler }\end{array}$ & $\begin{array}{l}\text { - E-posta haberleşmesi } \\
\text { - www ortamı } \\
\text { - Bilgisayarların bir ağ } \\
\text { üzerinden bağlanması } \\
\text { - } 1990-2000 \text { arası gelişimi } \\
\text { - "Web” kavramının } \\
\text { ortaya çıkması } \\
\text { - Tim Berners Lee } \\
\text { tarafından adlandırıldı }\end{array}$ & $\begin{array}{l}\text { - İş birlikçi çalışma ortamı } \\
\text { - 2000-2010 arası gelişimi } \\
\text { - Sosyal Web kavramının } \\
\text { ortaya çıkması } \\
\text { - O’Reilly Media tarafından } \\
\text { adlandırıldı }\end{array}$ & $\begin{array}{l}\text { - Verilerin birbiriyle bağlanması } \\
\text { ve ilişkilendirilmesi } \\
\text { - } 2010-2020 \text { arası gelişimi } \\
\text { - Anlamsal Web Kavramının } \\
\text { ortaya çıkması } \\
\text { - Tim Berners Lee } \\
\text { tarafından adlandırıldı }\end{array}$ \\
\hline $\begin{array}{l}\text { Yapılan } \\
\text { İşlem }\end{array}$ & $\begin{array}{l}\text { - Web sayfalarının } \\
\text { linklerle bağlanması } \\
\text { - İstatiksel Web } \\
\text { - Bilgilendirme } \\
\text { - Bilgi Merkezi }\end{array}$ & $\begin{array}{l}\text { - Insanların sosyal ağ kurmaları } \\
\text { - Sosyalleşme } \\
\text { - Paylaşma } \\
\text { - İnsan merkezli }\end{array}$ & $\begin{array}{l}\text { - Verilerin ilişkilendirilmesi } \\
\text { - Anlamsal Web } \\
\text { - Bilgiyi anlamlandırma } \\
\text { - Makine merkezli }\end{array}$ \\
\hline $\begin{array}{l}\text { Uygulama } \\
\text { Olanağı }\end{array}$ & $\begin{array}{l}\text { - Şirketler } \\
\text { - Sahip olma }\end{array}$ & $\begin{array}{l}\text { - Toplum } \\
\text { - Paylaşma }\end{array}$ & $\begin{array}{l}\text { - Bireysel } \\
\text { - Dinamik içerik birleştirme }\end{array}$ \\
\hline $\begin{array}{l}\text { İçerik } \\
\text { Üretimi }\end{array}$ & $\begin{array}{l}\text { - Şirketler üretir, } \\
\text { kullanıcılar okur/izler }\end{array}$ & $\begin{array}{l}\text { - Şirketler ve kullanıcılar } \\
\text { içerik üretir } \\
\text { - Şirketler kullanıcılar } \\
\text { içerik üretsin diye } \\
\text { platformlar oluşturur }\end{array}$ & $\begin{array}{l}\text { - Kullanıcılar kendi } \\
\text { uygulamalarını oluşturur } \\
\text { - Firmalar insanlar haklarında } \\
\text { söz etsin ve görünür olsunlar } \\
\text { diye çeşitli platformlarda } \\
\text { varlık gösterirler }\end{array}$ \\
\hline $\begin{array}{l}\text { Biçimsel } \\
\text { Olanağı }\end{array}$ & - Metin, Grafik & $\begin{array}{l}\text { - Çift yönlü iletişim/paylaşım, } \\
\text { metin, grafik, fotoğraf, } \\
\text { video, pod cast, PDF, vs. }\end{array}$ & $\begin{array}{l}\text { - } 3 \text { D portallar, çoklu kullanıcı, } \\
\text { arttırılmış gerçeklik, sanal } \\
\text { gerçeklik, sanal Web } \\
\text { dünyaları, sanal iş ve eğitim }\end{array}$ \\
\hline $\begin{array}{l}\text { Belirleyici } \\
\text { Özelliği }\end{array}$ & $\begin{array}{l}\text { - Web sayfasının } \\
\text { okunabilmesi } \\
\text { - Kullanıcının sayfa } \\
\text { kullanımında pasif kalması } \\
\text { - Bilgi alma (kullanıcı) }\end{array}$ & $\begin{array}{l}\text { - Web sayfasına yazılabilmesi } \\
\text { - Kullanıcının sayfa } \\
\text { kullanımında aktif olması } \\
\text { - Bilgi almak-bilgi } \\
\text { vermek (kullanıcı) }\end{array}$ & $\begin{array}{l}\text { - Web sayfası çalıştırılabilir } \\
\text { - Makinenin sayfa } \\
\text { kullanımında aktif olması } \\
\text { - Bilgi almak-vermek (makine) }\end{array}$ \\
\hline
\end{tabular}

Kaynak: Abdüsselam, vd.(2015) ile Naik, U. ve Shivalingaiah, D., (2008)'den uyarlanmıștır.

Tablo 1'de de görüldüğü gibi Web 2.0 teknolojisi ve onun sunduğu sosyal medya ortamları hayatımıza girene kadar internetin geleneksel medya mantığı ile işlediği ve internet kullanıcılarının e-posta göndermek dışında pasif birer izleyici olduğu aşikârdır. Web 2.0 ise süreci tersine çevirerek sosyal medya adı verilen internet siteleri aracılığıyla internet kullanıcılarına interaktif bir biçimde kendi medyalarının sahibi olma fırsatını tanımıştır. Günümüzde Web 3.0'ın gelişiminin bir neticesi olarak sosyal medya ortamları da biçimsel ve işlevsel olarak değişmeye başlamıştır. Özellikle Web 3.0'ın sunacağı yapay zekâ (öğrenen), üç boyut, artırılmış gerçeklik desteği ile sosyal medya ortamları tam anlamıla sanal bir deneyim sunmaya başlayacaktır (Whittaker, 2008; Ansari, 2018), ancak ne tür gelişmeler yaşanırsa yaşansın sosyal medyayı farklı kılan ana unsur, internet kullanıcılarına kendi içeriklerini üretme ve paylaşma özgürlüğü sağlamasıdır.

Yukarıda da söz edildiği üzere sosyal medya özünde kullanıcı içerikli ve etkileşimli web sitelerini ifade etmektedir. Birbirinden farklı özelliklere sahip birçok sosyal medya sitesi, bir diğer adıyla sosyal medya araçları bulunmaktadır. Bu araçlar kendi aralarında sosyal ağlar, bloglar, mikrobloglar, medya paylaşım siteleri ve forumlar gibi farklı türlere ve özelliklere ayrılmaktadır. Aşağıda söz konusu araçlar kısaca açıklanmaktadır. 
Sosyal ağlar, insanların kişisel bilgilerini paylaştığı; video, fotoğraf, müzik, haber gibi nesne paylaşımında bulunduğu ve bu ortamlarda bulunan başka kişilerle iletişim kurduğu internet toplulukları olarak kabul edilmektedir (Koçoğlu, 2019, s. 262). Sosyal ağlar, günümüzde destekledikleri görüntü ve ses formatları gibi özellikleri ve interaktif yapıları ile insanların tanıdıkları ile iletişim kurduğu günlük aktivite alanları olarak kabul edilmektedir (Sharma ve Godiyal, 2016, s. 157).

Bloglar, Türkçe ağ günlükleri veya çevrimiçi günlükler olarak adlandırılmakta ve internet kullanıcılarına teknik bilgi gerekmeksizin içerik oluşturma olanağı sunmaktadır (Topa Çiftçi, 2017, s. 56-57). Bloglar, internet kullanıcılarına kendi yorumlarıyla haber ve bilgi paylaşma olanağı sunan kişisel bir yayın aracı olarak da görülmektedir (Jarreau, 2018, s. 143). Bloglar, blog yazarlarına hızlı geri bildirim almalarını sağlayacak şekilde tasarlanmış, kronolojik olarak içerik girmelerine olanak sağlayan bir ortam olarak öne çıkmaktadır (Sánchez-Villar, 2018, s. 41-42).

Mikrobloglar, adından da anlaşılabileceği üzere blog içeriklerinin mikro düzeyde gerçekleştiği sosyal medya ortamlarıdır. Sayfa şeklinde eş zamanlı akışa sahip mikrobloglar, gönderi başına genellikle 140 karakter ile sınırlıdır (Yıldırım vd., 2019, s. 5581). Dünyada ve Türkiye'de en popüler mikroblog sitesi Twitter'dır. Twitter, dünya genelinde aylık 330 milyon aktif kullanıcı ile en çok üyeye ve aktif kullanıcıya sahip olan mikroblog olarak öne çıkmaktadır (Statista, 2019).

Medya paylaşım siteleri/ortamları, çeşitli video ve fotoğraf paylaşım sitelerini tanımlamak üzere kullanılan bir tanımdır. Medya paylaşım siteleri, ilk kez video destekli forum olarak tasarlanan video paylaşım siteleri ile ortaya çıkmıştır (Kawamoto vd., 2016, s. 1). YouTube, Dailymotion ve Vimeo, günümüzün en popüler video paylaşım siteleridir (Monteiro vd., 2018, s. 7). Fotoğraf paylaşım sitelerinde ise geliştirilmiş yorum yazabilme alanı ve interaktif yapısı ile Instagram öne çıkmaktadır (Schöps vd., 2017, s. 475). Instagram'ın ardından Flickr ve Picassa gelmektedir.

Forumlar, farklı topluluklar için farklı ilgi alanlarına özel olarak oluşturulmuş özel tartışma ve bilgi paylaşımı ortamlarıdır (Tadesse vd., 2019, s. 44885). Forumlar, farklı amaçlar doğrultusunda açılan ve moderatörler tarafından üye kabulü ve üye çıkışı sağlanan topluluk siteleri özelliği taşımaktadır.

Yukarıda da görüldüğü üzere, sosyal medya ortamları/siteleri farklı tür ve özelliklerde olabilmektedir. Bu ortamları sosyal medya yapan unsur ise kullanıcı içerikli ve interaktif olmalarıdır. Bu bağlamda, interaktif ve kullanıcı içerikli yapıya sahip her web sitesi ve mobil site uygulaması, özünde bir sosyal medya ortamıdır. Sosyal medyanın marka ve kuruluşlara sunduğu firsatların da anlaşılmasıyla birlikte günümüzde ticari ve ticari olmayan birçok kuruluş, sosyal medya hesapları üzerinden hedef kitleleri ile iletişim kurma çabasına girmiştir. Hatta günümüzde irili ufaklı tüm markalar sosyal medya pazarlamasına odaklanmakta ve marka imajında değer artışı yaratmayı hedeflemektedir (Aytan ve Telci, 2014, s. 2). Bu durum, aşağıda yer alan "Markaların Sosyal Medyadaki Varlık Nedenleri ve Faaliyetleri” başlığı altında irdelenmektedir.

\section{Markaların Sosyal Medyadaki Varlık Nedenleri}

Markaları standart bir ürün ya da hizmetten ayıran en önemli unsur onların hedef kitleleri ile iletişim kuruyor olmasıdır. Logosu, renkleri, ambalajı, sloganı gibi ilk bakışta görünen temel ögeleri bile markanın kendisi ile ilgili bir şeyler söylediğini göstermektedir (Uztuğ, 2002, s. 14). Ancak günümüz ağırlaşmış rekabet şartları altında bu sınırlı ve tek 
yönlü iletişim işlevsizleşmiş, bir kimliği ve karakteri olan, tüzel kişiden çok birey olarak algılanan markaların çok daha sosyal olmalarını gerekli kılmıştır. Bu noktada interaktif iletişime olanak sağlayan tek platform olarak sosyal medya markalara önemli firsatlar sunmaktadır. Sosyal medya, kuruluşlara müşterileri ile iletişim içinde kalmalarına olanak sağlayan önemli bir iletişim aracı olarak kabul edilmektedir. Bu nedenle dünya çapındaki birçok dev marka pazarlama faaliyetlerini sosyal medyaya odaklamıştır (Akbar ve Özgül, 2018). Sosyal medyanın zaman ve mekân kısıtını aşması ve sunduğu diyalog ortamı ise bu süreci çok daha hızlı ve etkin bir hale dönüştürmüştür. Ayrıca, sosyal medyada marka iletişimi üzerine yapılan araştırmalar canlı renkler içeren fotoğraf, video ve animasyon gibi farklı biçimlerdeki paylaşımların markaların popülerliğini artırdığını ortaya koymuştur (Jakste vd. 2017, s. 1373). Bu açıdan bakıldığında sosyal medya markalar açısından interaktif bir iletişim ortamının çok daha ötesindedir.

Sosyal medya, markalara düşük maliyet ile hedef kitlelerinin büyük çoğunluğuna ulaşma olanağı sağlayan tek ortamdır (Gao vd. 2018, s. 45). Sosyal medyanın etkileşimli ve eş zamanlı doğası müşteri ve marka ilişkisine olanak sağlamaktadır (Kupfer, 2018, s. 26). Günümüzde markaların sosyal medya üzerinden hedef kitleleri ile etkileşim kurmaları, markalara değer katan önemli bir unsur olarak kabul edilmektedir (Pitt vd. 2019, s. 130). Güney Kore'de yürütülen bir araștırma, markaların sosyal medya hesaplarında yer alan etkileşim, ilişkiye dayalı tecrübe ve eğlenceli içeriğin satın alma kararına olumlu biçimde yansıdığını ortaya koymuştur (Wang vd. 2019, s. 484-485). Endonezya'da gerçekleştirilen bir araştırma, özellikle ülkedeki yerel markaların markalaşma ve pazarlama sürecinde sosyal medyanın son derece önemli rol oynadığını ortaya koymuştur (Angeline, vd. 2019, s. 279). Pakistan'da yürütülen bir araştırma ise sosyal medyanın, marka farkındalığının oluşmasında, marka imajının pekişmesinde ve satın alma kararının oluşmasında önemli rol oynadığını ortaya koymaktadır (Ali vd. 2019, s. 150). Sosyal medya, marka farkındalığı ve marka imajına sunduğu katkıların yanı sıra; marka yöneticilerine müșterileri daha iyi anlama fırsatı da sağlamaktadır. Böylece marka, edindiği bu bilgiler ışığında daha doğru stratejik kararlar verebilmektedir (Kim vd. 2019, s. 22). Bununla birlikte küresel markalar sahip oldukları resmî sosyal medya hesapları üzerinden yerel müșterilerin kültürlerini de tanıma ve bu bağlamda hareket etme olanağı bulmaktadır (Gao vd. 2018, s. 48). Tüm bu verilerden yola çıkarak sosyal medyanın sahip olduğu etkileşimli yapısı nedeniyle kuruluşlara; müşteri profili, müşteri beklentileri, pazarın yapısı ve kültürel farklılıklarla ilgili son derece hayati veriler sunduğu aşikârdır. Literatürdeki tüm bu verilerden yola çıkarak sosyal medyanın kuruluşlar açısından hedef kitleleri ile oluşan interaktif ve dinamik bir süreci sağladığı, bunun yanı sıra hem kuruluşun hem de hedef kitlelerinin sesini duyurabildiği bir platform işlevi gördüğü söylenebilmektedir (Şengöz ve Eroğlu, 2017, s. 504). Bu noktadan hareketle sosyal medyanın kuruluşlara ve bireylere eşit firsatlar sunan medya ortamı olduğunu söylemek mümkündür.

Markalar açısından sosyal medya yönetiminde en önemli unsur sosyal medya hesaplarının nasıl kullanıldığıdır. Sosyal medya da geleneksel medyada olduğu gibi stratejik şekilde hareket edilmesi gereken bir platformdur. Bu bağlamda mesaj stratejisi, mesaj tonu, hedef kitle bölümlendirmesi hatta hedef kitle mikro bölümlendirmesi ve geri bildirim mekanizması yapılandırılması gibi unsurlar sosyal medya iletişiminin başarısını belirlemektedir. Sosyal medyanın kurumlar açısından ilişki inşa etme ve iletişim kurma pratiklerini kökten değiştirmesi ve değiștirmeye devam etmesi söz konusudur (Yüce ve Taşdemir, 2019, s. 1186). Bu noktadan hareketle bilinçli, planlı ve tutarlı sosyal medya stratejileri geliștirmeden sosyal medyada yürütülen her faaliyet, markaya faydadan çok 
zarar verebilmektedir. Aşağıda sosyal medya ve diyalojik döngü başlığı altında konu Kent ve Taylor'ın (1998) geliştirmiş olduğu "Diyalojik İletişim Teorisi" bağlamında ele alınıp tartışılmaktadır.

\section{Diyalojik İletişim Teorisi}

Kent ve Taylor'ın web sitelerinin ilişki geliştirme kapasitelerini ölçümlemek ve açıklamak amacıyla geliștirdikleri "Diyalojik İletişim Teorisi" diyalojik prensipler üzerine inşa edilmiştir (Özdemir ve Yamanoğlu, 2010, s. 12). Teori, özünde internet teknolojileri üzerinden kurum ve hedef kitlesi arasında web aracılığıyla kurulan diyalog ve gelișen ilişki bağlamında karşılıklı faydaya odaklanmaktadır. Kent ve Taylor, 1998 yılında yayımladıkları "Building Dialogic Relationships Through the Web" (Web ile Diyalojik İlișki İnşa Etme) isimli çalışmada, 1998 yılında henüz dünya genelinde 100 milyona yakın aktif internet kullanıcısının bulunduğunun ve bu sayının ilerleyen yıllarda katlanarak artacağının ve yaşanan bu gelişmelerin kurumlara ve kuruluşlara yeni firsatlar sunacağının altını çizmiştir (Kent ve Taylor, 1998, s. 327-328). Kent ve Taylor, yapmış oldukları ilk diyalojik iletişim çalışmasından dört yıl sonra, 2002 yılında yayımladıkları "Toward a Dialogic Theory of Public Relations" (Halkla İlişkilerin Diyalojik Teorisine Doğru) isimli ikinci diyalojik çalışmada, ilk çalışmalarında belirttikleri öngörülerin dört yll içinde gerçekleştiğine dikkat çekmişlerdir. Söz konusu çalışmada Kent ve Taylor; artık diyalojik iletişim teriminin birçok iletişim araştırmacısı ve uygulayıcısı tarafından kabul gördüğünü ve bu terimin kullanımının hızlı biçimde arttığını ifade etmişlerdir (Kent ve Taylor, 2002, s. 22).

Diyalojik iletişim teorisi ilk başta Grunig ve Hunt'un dört halkla ilişskiler modelinin sonuncusu olan çift yönlü simetrik iletişim modeli ile benzeştirilmekte ve karıştırılmaktadır ancak teori derinlemesine incelendiğinde aradaki önemli farklılıklar kendini göstermektedir (Okmeydan, 2019, s. 55). Bu bağlamda Grunig ve Hunt'ın söylemi, kurumların çift yönlü simetrik halkla ilişkileri uygulayabilmeleri için yapılandırılmış bir sistemin gerekliliği yönündedir. Ancak Kent ve Taylor'ın sözünü ettiği tam anlamıla ilişkisel bir etkileşimdir (Kent ve Taylor, 1998, s. 323). Özetle, çift yönlü simetrik model, kaynak ile alıcı arasında doğrusal işleyen bir iletişimden söz ederken diyalojik iletişim ise ilişki geliştirmeden ve ilişkiye dayalı karşılıklı etkileşimden söz ederek süreci bir adım daha ileriye taşımaktadır.

Diyalojik iletişimde daima diyalojik sürecin varlığı gerekmektedir. Diyalojik süreçte, sürece dahil olan taraflardan biri manipülatif, olumsuz veya dışlayıcı tutum içine girerse sonuç diyalojik olmayacaktır. Bu bağlamda diyalog, bir süreç değil bir iletişim veya ilişkinin ürünü olarak ortaya çıkmaktadır (Yağmurlu, 2013, s. 99). Kent ve Taylor, web sayfalarında diyalojik iletişimin söz konusu olabilmesi için beş ilke belirlemiştir. Bu ilkeler ve ilkelerin içerikleri sırasıyla aşağıdaki gibidir (Özoran, 2017, s. 16-17):

Diyalojik döngü: Diyalojik iletişimin ilk ilkesi olan diyalojik döngü, temel olarak kurum ve hedef kitlesi arasındaki geri bildirim döngüsünü ifade etmektedir. $\mathrm{Bu}$ noktada Kent ve Taylor'a göre kurumlar diyalojik iletişim için istekli olmalı ve web sitelerini bu amaca uygun olarak tasarlamalıdır. Bu süreçten sorumlu olan çalışanlar ise iyi iletişim becerilerine sahip olmalı, gelebilecek soruları yanıtlamalı ve kurumun politikalarını anlatabilmelidir.

Enformasyon kullanışlılığı: Söz konusu ilke hem web sitesinin diyaloğu destekler şekilde yapılanması hem de faydalı içerikler sunması açısından iki fazlı bir süreci ifade etmektedir. 
Bu bağlamda kuruluşların web siteleri, tüm kamulara fayda sağlayabilecek içeriğe sahip olmalıdır. Ayrıca web sitesi, ilgili kamuların her türlü soru ve endişelerini iletebileceği diyaloğa açık olarak tasarlanmalıdır.

Yeniden ziyaret sağlama: Bu ilke, kurumların web sitelerini tekrar ziyaret ettirmeye odaklanmaktadır. Bunun için güncel, değişen konulara sahip, özel forumlar, çevrim içi yorum ve soru-cevap bölümleri olan çekici bir yapıya sahip web sitesi gerekmektedir. Tüm bunların yanı sıra web siteleri, kaydedilebilir bilgi, doküman ve sık sorulan sorular gibi bölümlerin de olduğu tek yönlü iletişim özelliği taşıyan unsurlar da barındırmalıdır.

Arayüzün kullanışlılığı: Bu ilke tamamen sitenin yapısallığı ve kullanım kolaylığı ile ilgilidir. $\mathrm{Bu}$ bağlamda web sitesini ziyaret eden kimseler, sitenin kullanımını ve aradıkları bilgiyi kolayca bulabilmelidirler. Bu noktada içerik tablosu ve site haritası gibi uygulamalar, ziyaretçilere kolaylık sağlayan unsurlar olarak tanımlanabilmektedir.

Ziyaretçilerin korunması: Bu son ilke, web sitesinin ziyaretçilere kaliteli deneyim yaşatma zorunluluğunu ifade etmektedir. İnternet sitelerinin reklam ve satış değil, etkili birer etkileşim aracı olarak görülmeleri gerekliliğini vurgulamaktadır.

Yukarıda açıklanan beş ilkeden ilki olan diyalojik döngü, kuruluşun iletişime açık olup olmadığını gösteren bir işaret olarak kabul edilmektedir. Bu nedenle birçok araştırmacı diyalojik döngü ilkesini en önemli ilke olarak kabul etmektedir. Ancak web tabanlı bir diyaloğun oluşabilmesi için öncelikle hedef kitlenin, kuruluşun web sitesini ve web tabanlı ortamlarını ziyaret etmesi gerekliliği karşımıza çıkmaktadır. Bu gerekliliğin sağlanabilmesi için diğer dört ilkenin gerekliliği kendini göstermektedir. Bu nedenle diyalojik ilkeler arasında bir önem sırası oluşturmak pek doğru olmayacaktır.

\section{Yöntem}

Bu çalışma Türkiye'de faaliyet gösteren markaların Facebook hesaplarında ortaya çıkan diyalojik ilkeleri belirlemeyi ve tartışmayı amaçlamaktadır. Bu noktadan hareketle Boom Social'ın Eylül 2019 "Social Brands" (Sosyal Markalar) Raporuna göre, sosyal medyayı en iyi kullanan ve Türkiye'de faaliyet gösteren 100 markadan ilk beşi araștırma örneklemine dahil edilmiştir. Boom Social, markaların sosyal medya ölçümleme sürecinde resmî Facebook, Twitter ve Instagram hesaplarını incelemekte ve skorlandırmayı etkileşim oranına göre yapmaktadır. İleti başına etkileşim üzerine odaklanan Boom Social, her ay sosyal medyayı en iyi kullanan 100 sosyal markayı açıklamaktadır. Tablo 2'de Boom Socail tarafından Facebook'u en iyi kullandığı belirtilen ve amaçlı örneklem yöntemine göre araştırmaya dahil edilen ilk beş marka yer almaktadır. Farklı sektörlerde faaliyet gösteren bu markalar sırasıyla; Netflix, Madame Coco, Türk Hava Yolları, Ziraat Bankası ve Mutlu Akü'den oluşmaktadır.

Tablo 2: Sosyal Medyayı En L̇yi kullanan 5 Marka

\begin{tabular}{|l|l|c|}
\hline SIRA & SAYFA & SKOR \\
\hline 1 & Netflix & 85 \\
\hline 2 & Madame Coco & 85 \\
\hline 3 & Türk Hava Yolları & 83 \\
\hline 4 & Ziraat Bankası & 83 \\
\hline 5 & Mutlu Akü & 81 \\
\hline
\end{tabular}

Kaynak: Boom Social Eylül 2019 Raporu, https://www.boomsocial.com/Social-Brands/2019/Eylul/Top100

Tablo 2'de yer alan ve amaçlı örneklem yöntemine göre seçilen beş markanın resmî Facebook sayfalarına yönelik niceliksel içerik analizi yöntemi ile veri edinilmiștir. İçerik 
analizi; insanların, olguların veya olayların gözlem, görüşme veya sorular yoluyla araştırılmasından ziyade önceden kayıt altına alınan materyallerin incelenmesini ifade etmektedir (Güçlü, 2019, s. 168). İçerik analizi, bir dökümanda değerli görülen içeriği toplama ve analiz etmeye dayalı bir tekniktir. Analiz edilen içerik; sözcükler, düşünceler, anlamlar, resimler, görseller, semboller veya temalar gibi iletilebilen herhangi bir göndermeden meydana gelebilmektedir (Neuman, 2019, s. 466). Bu çalışmanın içerik analizi sürecinde edinilen veriler örneklem grubunda yer alan beş markanın resmî Facebook hesaplarında 1 Ekim ve 1 Aralık 2019 tarihleri arasında yapmış oldukları paylaşımlar ile sınırlıdır. İçerik analizine tabi tutulacak dokümanlar, elektronik verilerin üzerine de kurgulanabilmektedir. Böylece mesajlar, e-postalar, e-gruplar, web sayfaları, bloglar gibi çok geniş bir yelpaze, elektronik veri toplama aracı olarak kullanılabilmektedir (Baş ve Akturan, 2008, s. 119). Amaçlı örneklem ise önceden tanımlanarak belirlenmiş amaca uygun birimlerin incelenmesini ifade etmektedir (Erdoğan, 2007, s. 176). Olasılık temeli olmayan bu örnekleme yöntemi, araştırmanın amacına bağlı olarak bilgi açısından zengin durumların seçilerek derinlemesine incelenmesine ve araştırma yapılmasına olanak sağlamaktadır (Başaran, 2017, s. 490). Bununla birlikte nitel araştırmalarda örneklem büyüklügünden ziyade veri doygunluğuna ulaşılması esastır (Creswell, 2019, s. 82). Bu çalışmada örneklem grubunda yer alan beş markanın resmî Facebook sayfaları üzerinde Kent ve Taylor'ın (1998) diyalojik ilkeleri baz alınarak diyalojik iletişim düzeyleri açıklanmaya çalışılmaktadır. Kent ve Taylor'ın, web sitelerinin diyalojik düzeylerini açıklamak üzere geliştirmiş oldukları bu teorinin, bir sosyal ağ olan Facebook'a uyarlanması ve araştırma modelinin oluşturulmasında Waters ve arkadaşları (2011) ile Yağmurlu'nun (2013) çalışmalarından yola çıkılarak uyarlama yapılmıştır. Bu modele göre Kent ve Taylor'ın belirlemiş olduğu beş diyalojik ilkeden; diyalojik döngü, enformasyon kullanışlılığı, yeniden ziyaret sağlama ve ziyaretçilerin korunması Facebook'a uyarlanarak çeşitli analiz birimleri oluşturulmuştur. Ancak bu analiz birimlerine dördüncü ilke olan arayüzün kullanışlılığı, Facebook'un kendine ait standart bir arayüze sahip olması nedeniyle dahil edilmemiştir. Araştırmada, oluşturulan bu analiz birimleri üzerinden örneklem içerisinde yer alan markaların Facebook sayfalarına içerik analizi gerçekleştirilmiştir. Araştırma modeli detaylı bir biçimde Tablo 3'te yer almaktadır.

Tablo 3: Araștırma Modeli

\begin{tabular}{|l|l|}
\hline Diyalojik döngü: & $\begin{array}{l}\text { - Yapılan takipçi yorumları } \\
\text { - Cevaplanan takipçi yorumları } \\
\text { - Diğer etkileşimler }\end{array}$ \\
\hline Enformasyon kullanışııı̆ı: & $\begin{array}{l}\text { - Haber linkleri } \\
\text { - Ticari olmayan bilgilendirici paylaşımlar }\end{array}$ \\
\hline Yeniden ziyaret sağlama: & $\begin{array}{l}\text { - Son bir aydaki paylaşım sayıları (Güncellik) } \\
\text { - Biçimsel içerikler (fotoğraf, video, GIF vs.) }\end{array}$ \\
\hline Arayüzün kullanışı̆ıı̆ı: & $\begin{array}{l}\text { - Facebook standart bir arayüze sahip olduğundan } \\
\text { bu ilke değerlendirme dışı bırakılmıştır. }\end{array}$ \\
\hline Ziyaretçilerin korunması: & $\begin{array}{l}\text { - Kurumun resmî web sayfasında Facebook butonu } \\
\text { - Resmî Facebook sayfasında kurumun web linki } \\
\text { - Son bir ayda değişen takipçi sayısı }\end{array}$ \\
\hline
\end{tabular}

Kaynak: Waters vd., (2011) ile Yağmurlu (2013)'ten uyarlanmıştır.

Tablo 3'te yer alan modelde görüldüğü üzere diyalojik ilkeler Facebook'a uyarlanarak çeşitli analiz birimleri oluşturulmuştur. İncelenmesi amaçlanan bu analiz birimleri aynı zamanda araștırma sorularına da ıșık tutmaktadır. Bu bağlamda oluşturulan araștırma soruları aşağıdaki gibidir. 


\section{Araştırma Soruları}

Araştırma sorusunda araştırmacının net bir şekilde neyi tam olarak incelemek istediğini bilmesi ve bunu ifade edebilmesi esastır (Christensen vd., 2015, s. 93). Nitel araştırmalar en az bir temel soru veya birkaç alt soru sormakta ve keşfetmek, anlamak, ortaya çıkarmak gibi amaçlar taşımaktadır (Creswell, 2019, s. 151). Bu çalışmada da örneklem grubunda yer alan markaların resmî Facebook hesaplarının Kent ve Taylor'ın geliştirmiş olduğu diyalojik ilkeler bağlamında incelenmesi araştırma sorularında belirleyici rol oynamaktadır. Bu noktadan hareketle araștırmanın soruları aşağıdaki gibidir:

\section{A.S Markaların Facebook hesaplarında diyalojik döngü ilkesi ortaya çıkmakta mıdır?}

$\boldsymbol{A}_{\mathbf{S}} \boldsymbol{S}_{2}$ Markaların Facebook hesaplarındaki içerikler enformasyon kullanışlılı̆̆ı ilkesi bakımından faydalı enformasyon sunmakta midır?

$\mathrm{A}_{\mathbf{3}} \mathrm{S}_{3}$ Markalar Facebook sayfalarında yeniden ziyaret sağlama ilkesini sağlamak adına ne tür paylaşımlar yapmaktadır?

A.S Markaların Facebook sayfaları ziyaretçilerin korunması ilkesi bağlamında incelendiğinde takipçi sayısını muhafaza edebilmekte midir?

\section{Araştırmanın Güvenilirliği}

Veri toplamak için testler ya da diğer ölçme araçları kullanıldığında bu araçların güvenilir veri sunduğundan emin olmak gerekmektedir. Güvenirlilik ise bir dizi ölçümün birbirleriyle tutarlı olmasını ifade etmektedir (Gliner vd., 2015, s. 153). Ancak nitel araștırmalarda, araștırma amacının genelleme yapmak değil; belirli bir konuyu derinlemesine incelemek olması (Sönmez ve İlgün, 2018, s. 381-382) nicel araștırmaların aksine nitel araştırmalarda çok daha az sınama yöntem ve formüllerinin var olmasına neden olmaktadır. Bu noktadan hareketle nicel araştırmalarda var olan geçerlilik ve güvenirlilik, nitel araştırmalarda çoğunlukla inanılırlık ve sonuçların doğruluğu olarak nitelenmektedir. Bu noktada ise yöntem, veri, teori, araştırma üçgenlemesi, uzman görüşü, katılımcı teyidi gibi yöntemler söz konusu olmaktadır (Başkale, 2016, s. 23). Bu çalışmada ise araștırma güvenilirliğini/inanılırlığını artırmak adına Waters vd., (2011) ve Yağmurlu'nun (2013) farklı kuruluşların sosyal medya hesaplarında ortaya çıkan diyalojik iletişim ilkelerini belirlemek üzere yaptıkları araştırmalardan uyarlamaya gidilmesine rağmen bir alan uzmanıyla birlikte araştırmaya ait kod formları oluşturulmuştur. Kodlayıcılar arasındaki güveni ortaya koyabilmek için Miles ve Huberman'ın (1994) formülünden yararlanılmıştır. Miles ve Huberman, üzerinde uzlaşılan kod sayısının toplam uzlaşılan ve uzlaşılamayan kod sayısına bölünmesiyle ortaya çıkan oranı, kodlayıcılar arasındaki güvenilirlik olarak tanımlamaktadır. Buna göre oranın \%80'e yakın, hatta veri setinin büyüklüğü doğrultusunda \%90'dan fazla olması kodlayıcı güvenirliliği açısından önerilmektedir. Yine Miles ve Huberman (1994, s. 64) "Güvenilirlik= Görüş Birliği / (Görüş Birliği + Görüş Ayrılığı) x 100" formülü ile nitel araştırmalarda güvenilirliğin hesaplanabileceğini belirtmiştir. Buna göre bu çalışmada her iki araştırmacı tarafından toplam 24 kod oluşturulmuş, 22 kod üzerinde görüş birliğine varılırken 2 kodda görüş ayrılığı ortaya çıkmıştır. Verilen formüle göre kodlayıcılar arası güvenilirlik \%91.6 olarak belirlenmiş ve güvenilirliğin yüksek olduğu sonucuna varılmıştır. Özünde verilerin analiz sürecini ifade eden kodlama bu çalışmada, açık kodlama olarak adlandırılan verilerin ayrı ayrı parçalara ayrılarak incelenmesi (Güçlü, 2019, s. 301) amacıyla gerçekleștirilmiştir. Buna göre elde edilen bulgular, bir sonraki başlıkta sunulup yorumlanmıştır. 


\section{Bulgular}

Araştırmanın bulguları, incelenen markaların diyalojik iletişimini saptamak amacıyla Kent ve Taylor'ın (1998) geliştirdiği; 'diyalojik döngü', 'enformasyon kullanışlılı̆̆ı', 'yeniden ziyaret sağlama', 'arayüzün kullanışlılığı' ve 'ziyaretçilerin korunması' olmak üzere beș diyalojik ilke doğrultusunda yorumlanmıştır.

\section{Diyalojik Döngü Ilkesine Iliş̧kin Bulgular}

Diyalojik iletişim ilkelerinin ilki olan diyalojik döngü, kuruluş ve hedef kitleleri arasında ortaya çıkan çift yönlü iletişim ve diyalog uzunluklarına odaklanmaktadır. Bu noktada markaların yapmış oldukları paylaşımlar üzerinden hedef kitleleri ile ortaya çıkan etkileşim diyalojik döngüye işaret etmektedir. Araştırma kapsamında yer alan markaların Facebook sayfalarındaki diyalojik döngü Tablo 4'te özetlenmektedir.

Tablo 4: Diyalojik Döngü İlkesine İlișkin Bulgular

\begin{tabular}{|l|c|c|c|c|c|}
\hline & $\begin{array}{c}\text { Toplam } \\
\text { Paylaşım }\end{array}$ & $\begin{array}{c}\text { Takipçi } \\
\text { Yorumları }\end{array}$ & $\begin{array}{c}\text { Yanıtlanan } \\
\text { Takipçi Yorumları }\end{array}$ & $\begin{array}{c}\text { Emoji ile Yanitlanan } \\
\text { Takipçi Yorumları }\end{array}$ & $\begin{array}{c}\text { Takipçi Emoji } \\
\text { Gönderimi }\end{array}$ \\
\hline Netflix & 40 & 3.321 & 1 & 0 & 9.837 \\
\hline Madame C. & 112 & 40.324 & 0 & 0 & 16.320 \\
\hline THY & 41 & 1.025 & 347 & 12 & 38.352 \\
\hline Ziraat B. & 24 & 3.968 & 428 & 0 & 85.623 \\
\hline Mutlu A. & 47 & 12.438 & 611 & 7 & 29.281 \\
\hline
\end{tabular}

Tablo 4'e göre Netflix'in 1 Ekim 2019-1 Aralık 2019 tarihleri arasında toplam 40 içerik paylaştığı ve bu içeriklere sayfa takipçileri tarafından toplam 3.321 yorum yazıldığı görülmektedir. Sayfa yönetimi tarafından yapılan yorumlardan sadece birine yanıt verilmesi dikkat çekicidir. Söz konusu yanıt, bir takipçinin "Aralık gelsin artık" yorumuna Netflix tarafından yazılan "Hemen" cevabından ibarettir. Bununla birlikte iki ay içinde paylaşılan içeriklere sayfa takipçileri tarafından toplam 9.837 adet emoji ile karşılık verilmiştir. Söz konusu veriler ışığında Netflix'in resmî Facebook hesabında diyalojik iletişim ilkelerinin ilki olan diyalojik döngünün ortaya çıkmadığı saptanmıştır.

Madame Coco'nun 1 Ekim 2019-1 Aralık 2019 tarihleri arasında toplam 112 içerik paylaşımında bulunduğu belirlenmiştir. Paylaşılan içeriklere sayfa takipçileri tarafından 40.324 yorum yazılmış ve bu yorumların tümü sayfa yönetimi tarafından cevapsız bırakılmıştır. Ancak söz konusu yorumlar, markanın etkileşimi artırmak adına "MadameCoco" hashtagi (\#) ile güzel yorumlar yazan takipçilerine çekiliş sonucunda hediye dağıtmasından kaynaklanmaktadır. Bu nedenle paylaşımların altında yer alan takipçi yorumları "Harikasın \#MadameCoco, Her şeyin güzel \#MadameCoco, \#MadameCoco evim seninle güzel" gibi standartlaşmış takipçi yorumlarından oluşmaktadır. Bunun yanı sıra markanın iki ay içinde paylaşmış olduğu 112 içeriğe takipçileri tarafından 16.320 emoji butonu kullanımı ile karşılık verilmiştir. Tüm bu veriler ıșığında Madame Coco'nun resmî Facebook hesabında tek yönlü iletişim olduğu saptanmış ve diyalojik döngünün söz konusu olmadığı belirlenmiştir.

Türk Hava Yolları'nın (THY) 1 Ekim 2019-1 Aralık 2019 tarihleri arasında yapmış olduğu paylaşımlar incelendiğinde markanın iki aylık süre içinde toplam 41 adet içerik paylaştığ ve bu içeriklere sayfa takipçileri tarafından toplam 1.025 yorum yazıldığı görülmüştür. Bununla birlikte söz konusu takipçi yorumlarından 347'sine THY tarafından cevap verildiği görülmüştür. Yanıtlanan ve yanıtsız bırakılan içerikler incelendiğinde markanın; soru, şikâyet, öneri ve destek mesajlarına mutlaka yazılı olarak veya gülen yüz, kalp, çiçek gibi emojiler aracılığıyla cevap verdiği belirlenmiștir. Yanıtsız bırakılan mesajların ise 
hakaret içeren aşırı takipçi yorumları ve markaya yöneltilmeyen takipçi yorumlarından oluştuğu saptanmıştır. Yanıtlanan takipçi yorumları değerlendirildiğinde markanın, destek mesajları dahil yanıtlaması gereken tüm takipçi yorumlarını yanıtladığı ve takipçilerle diyalog kurmaktan kaçınmadığı ortaya çıkmıştır. Bununla birlikte markanın ilgili tarihler arasında yapmış olduğu 41 paylaşıma takipçileri tarafından 38.352 emoji butonu ile karşılık verildiği saptanmıştır. Söz konusu emojilerin çoğunlukla kalp ve beğenme işaretlerinden oluştuğu gözlemlenmiştir. Söz konusu veriler ışığında THY'nin resmî Facebook sayfasında diyalojik iletişim ilkelerinin ilki olan diyalojik döngünün ortaya çıktığı görülmektedir.

Ziraat Bankası'nın 1 Ekim 2019-1 Aralık 2019 tarihleri arasında yapmış olduğu 24 paylaşıma takipçileri tarafından 3.968 yorum yapıldı̆̆ı ve bu yorumlardan 428'ine yanıt verildiği saptanmıştır. Yanıtlanan ve yanıtsız bırakılan takipçi yorumları incelendiğinde soru, öneri, destek ve şikâyet içerikli takipçi yorumlarının mutlaka yanıtlandığı gözlemlenmiştir. Aşırı eleştiri veya markaya yönelik olmayan takipçi yorumlarının ise yanıtsız bırakıldı̆̆ı görülmüştür. Bununla birlikte takipçilerden gelen bazı soru, öneri ve şikâyet içerikli yorumların altında küçük diyalogların oluştuğu görülmüştür. Söz konusu veriler ışığında Ziraat Bankası'nın Facebook sayfasında çift yönlü iletişimin varlığı kendini göstermekle birlikte markanın takipçileri ile diyaloğa girmekten kaçınmadığı gözlemlenmiștir. Aynı zamanda Ziraat Bankasının ilgili tarih aralığında yapmış olduğu 24 paylaşım, sayfa takipçileri tarafından 85.623 emoji butonu ile karşılık almıştır. Söz konusu emojilerin çoğunlukla beğenme ve kalp işaretlerinden oluştuğu gözlemlenmiştir. $\mathrm{Bu}$ noktadan hareketle Ziraat Bankası örneğinde de diyalojik iletişim ilkelerinden ilki olan diyalojik döngünün ortaya çıktığı görülmektedir.

Mutlu Akü'nün 1 Ekim 2019-1 Aralık 2019 tarihleri arasında yapmış olduğu 47 paylaşıma takipçileri tarafından toplam 12.438 yorum yapıldı̆̆ı görülmüştür. Ancak söz konusu takipçi yorumları ağırlıklı olarak marka tarafından yapılan ödüllü soru yarışmalarına verilen yanıtlardan oluşmaktadır. Söz konusu ödüllerin tablet bilgisayarlar, taşınabilir şarj cihazları, kablosuz hoparlörler ve kablosuz kulaklıklar gibi cazip hediyelerden oluştuğu ve takipçilerin ilgisini yoğun biçimde yakaladığı saptanmıştır. Ancak bunun dışında, takipçiler tarafından yapılan soru, öneri, destek ve şikâyet içerikli yorumlara 611 takipçi yorumuna marka tarafından yanıt verildiği ve marka ile takipçileri arasında küçük diyalogların oluştuğu tespit edilmiştir. Yanıtsız bırakılan takipçi yorumlarının ise yarışma sorularına verilen cevaplar ve yorum alanına bırakılan emojilerden oluştuğu gözlemlenmiştir. Bunun yanı sıra markanın ilgili tarih aralığında yapmış olduğu 47 paylaşım, sayfa takipçileri tarafından 29.281 emoji butonu ile karşılık almıştır. Söz konusu butonların beğenme, kalp ve gülen yüz işaretlerinden oluştuğu gözlemlenmiştir. Söz konusu veriler ışığında Mutlu Akü örneğinde de diyalojik iletişim ilkelerinin ilki olan diyalojik döngünün ortaya çıktığı görülmektedir.

Beş markanın Facebook sayfaları incelendiğinde beş markadan THY, Ziraat Bankası ve Mutlu Akü'nün Facebook sayfalarında diyalojik iletişim ilkelerinin ilki olan diyalojik döngünün ortaya çıktığı görülmüştür. Netflix ve Madame Coco'nun ise Facebook sayfalarında diyalojik döngüden söz edilememektedir.

\section{Enformasyon Kullanışııı̆ı İlkesine İlişkin Bulgular}

Enformasyon kullanışlılığı ilkesi, paylaşılan içeriklerin ticari amaç gütmeden tüm kamulara fayda sağlayacak biçimde olması gerektiğini belirtmektedir. $\mathrm{Bu}$ araștırma modelinde ise enformasyon kullanışlılığı ilkesinde tüm takipçiler için faydalı bilgiler 
içeren içerikler veya haber linkleri paylaşımları aranmaktadır. Bu bağlamda araştırma kapsamında yer alan markaların Facebook hesaplarında yer alan paylaşımlar Tablo 5'te yer alan kategori cetvelinde görülmektedir.

Tablo 5: Enformasyon Kullanışlılığı İlkesine İlişkin Bulgular

\begin{tabular}{|l|c|c|c|c|c|c|}
\hline & $\begin{array}{c}\text { Ürün/Hizmet } \\
\text { Tanıtımı }\end{array}$ & $\begin{array}{c}\text { Kurumsal } \\
\text { Haber/Duyuru }\end{array}$ & Promosyon & $\begin{array}{c}\text { Etkileşim } \\
\text { Kurma }\end{array}$ & $\begin{array}{c}\text { Faydalı } \\
\text { Enformasyon }\end{array}$ & Diğer \\
\hline Netflix & 29 & 0 & 0 & 10 & 0 & 1 \\
\hline Madame C. & 80 & 0 & 30 & 0 & 0 & 2 \\
\hline THY & 28 & 5 & 0 & 1 & 3 & 4 \\
\hline Ziraat B. & 4 & 12 & 0 & 0 & 3 & 5 \\
\hline Mutlu A. & 5 & 11 & 19 & 5 & 0 & 7 \\
\hline
\end{tabular}

Tablo 5'te görüldüğü üzere araștırmada yer alan markaların Facebook hesaplarındaki paylaşım içerikleri incelendiğinde Netflix, Madame Coco ve THY olmak üzere ilk üç markanın ağırlıklı olarak ürün ve hizmet tanıtımına yönelik içerik paylaşımında bulundukları saptanmıştır. Buna karşın Ziraat Bankası'nın ağırlıklı olarak kurumsal haber ve duyuru, Mutlu Akü'nün ise ödüllü yarışma soruları gibi promosyonel içerikler paylaştığı izlenmiştir. Enformasyon kullanışlılığı ilkesini karşılayan, ticari amaç gütmeyen tamamen bilgilendirici içerik paylaşımı ise ilgili tarih aralığında 41 paylaşım yapan THY'nin 3 paylaşımında ve yine ilgili tarih aralığında 47 paylaşım yapan Mutlu Akü'nün 3 paylaşımında görülmüștür. Diğer markaların paylaşım içerikleri incelendiğinde enformasyon kullanışlılığı ilkesini sağlayacak hiçbir içeriğin paylaşılmadığı görülmüştür.

Netflix'in Facebook sayfasında paylaştı̆̆ı kategorilerin başında platformda yer alan ve yer alacak olan yapımlarla ilgili tanıtımlar gelmektedir. Bunun dışında sayfa yönetiminin takipçilerle etkileșim kurmak adına paylaşmış olduğu dizi/film karakterlerinin resimleri ile "Sen hangi dizi karakterisin, bir maceraya çıkacak olsan kimi yanına alırdın" gibi içerikler ürettiği gözlemlenmiştir. Bunların dışında kategori cetvelinde "Diğer" kategorisi altında yer alan özel bir güne ait kutlama paylaşımı bulunmaktadır.

Madame Coco'nun paylaşım içerikleri göz önüne alındığında içeriklerin tamamen pazarlama amaçlı paylaşımlardan oluştuğu gözlemlenmekte ve takipçilere faydalı enformasyon sunulmadığı söylenebilmektedir.

THY'nin paylaşım kategorileri incelendiğinde; uçulan güzergahlar, sunulan hizmetler gibi ağırlıklı olarak pazarlama ve tanıtım içerikli paylaşımların yer aldığı görülmektedir. İkinci en çok paylaşlan kategorinin ise kurumun elde ettiği başarılar, yapılan yeni anlaşmalar ve filoya yeni katılan uçaklar gibi kurumsal haberlerden oluştuğu saptanmıştır. Bunun dışında özel günlere ait kutlama ve anma paylaşımları görülmüştür. Son olarak pazarlama amacı gütmeyen, enformasyon kullanışlılığı ilkesini karşılayabilecek 3 paylaşım izlenmiştir. Söz konusu paylaşımlar, havacılık-uçak yolculukları ile ilgili bilgilendirici içeriklerden oluşmuştur.

Ziraat Bankası tarafından paylaşılan kategoriler incelendiğinde en çok paylaşılan içeriğin kurumsal haberlerden oluştuğu saptanmıștır. Söz konusu haberler, yeni açılan şubelerden bankanın katıldığı tarım fuarlarına kadar kurumla ilgili tüm haber ve gelişmeleri kapsamaktadır. Bunun yanı sıra, tarım kredisinin nasıl kullanılacağı, üniversite öğrencilerinin nerelerden burs bulabileceği gibi enformasyon kullanışlılığı ilkesini karşılayabilecek 3 bilgilendirici içeriğin paylaşıldığı gözlemlenmiştir. 
Mutlu Akü'nün Facebook sayfasında paylaştığı içerikler kategorize edildiğinde ise markanın çoğunlukla yarışma içerikli paylaşımlar yaptığı tespit edilmiştir. En çok paylaşılan ikinci içerik ise kurumsal haberlerden oluşmuştur. Üçüncü sırada ise özel günlere ait anma ve kutlama paylaşımları yer almıştır. Dördüncü sırada ise ürün-hizmet tanıtımını ve sayfa etkileşimini artırmaya yönelik paylaşımlar görülmüştür. Söz konusu paylaşımlar, "Manuel mi otomatik mi; Start stoplu mu standart mı; Sedan mı hatchback mi" gibi takipçilerin görüşlerini alıp etkileşimi artırmaya yönelik paylaşımlardan oluşmuştur.

Edinilen veriler doğrultusunda araştırma kapsamında yer alan markaların ticari amaç gütmeyen tüm kamulara fayda sağlayacak biçimde içerik paylaşmaya istekli olmadıkları saptanmıștır. Buna karşın araştırma kapsamında yer alan markaların Facebook hesaplarından çoğunlukla ürün-hizmet tanıtımı, kurumsal haber duyurumu ve çeşitli promosyonel içerikler paylaşma eğiliminde oldukları görülmüştür. Bu noktadan hareketle araștırma kapsamında yer alan THY ve Ziraat Bankası olmak üzere iki markanın toplam altı paylaşım ile enformasyon kullanışlılığı ilkesini karşılayabilecek çok az sayıda içerik paylaştığı, diğer üçünün ise enformasyon kullanışlılığı ilkesini hiç karşılayamadığı söylenebilmektedir.

\section{Yeniden Ziyaret Sağlama İlkesine İlişkin Bulgular}

Diyalojik ilkelerden üçüncüsü olan yeniden ziyaret sağlama ilkesi, güncellik, interaktivite (etkileşim) ve çekici bir yapıyı ifade etmektedir. Söz konusu ilke, yapısı gereği zaten interaktif bir platform olan sosyal medyaya uyarlandığında güncel içerik ile biçimsel olarak renkli ve ilgi çekici paylaşımlar söz konusu olmaktadır. Bu araştırma kapsamında yer alan markaların 1 Ekim 2019-1 Aralık 2019 tarihleri arasında biçimsel (format) olarak yapmış oldukları paylaşımlar Tablo 6'da görülmektedir.

Tablo 6: Yeniden Ziyaret Sağlama İlkesine İlişkin Bulgular

\begin{tabular}{|l|c|c|c|c|c|c|}
\hline & Metin & Fotoğraf & Video & GIF & Diğer & Toplam \\
\hline Netflix & 5 & 19 & 16 & 0 & 0 & 40 \\
\hline Madame C. & 0 & 112 & 0 & 0 & 0 & 112 \\
\hline THY & 0 & 34 & 6 & 1 & 0 & 41 \\
\hline Ziraat B. & 0 & 24 & 0 & 0 & 0 & 24 \\
\hline Mutlu A. & 0 & 47 & 0 & 0 & 0 & 47 \\
\hline
\end{tabular}

Tablo 6'ya göre araştırma kapsamında yer alan markaların ilgili tarihler arasında Facebook sayfalarından yapmış oldukları paylaşım sıklıkları farklılıklar gösterse de tüm markaların sayfalarının güncel olduğu belirlenmiștir. Bunun yanı sıra tüm markaların biçimsel olarak paylaşımlarının çoğunluğunu fotoğrafların oluşturduğu buna ek olarak Netflix'in video içeriği de paylaştığı saptanmıştır. Bu noktadan hareketle araştırmaya konu olan markaların Facebook sayfalarında ilgi çekici görsel içerikli paylaşımlara yöneldikleri belirlenmiştir. Bu durum diyalojik iletişim ilkelerinin üçüncüsü olan yeniden ziyaret sağlama ilkesinin tüm markalar tarafından karşılandığını ortaya koymaktadır.

\section{Ziyaretçilerin Korunması İlkesine İlişkin Bulgular}

Son diyalojik ilke olan ziyaretçilerin korunması ilkesi, web sitesi ziyaretçilerine kaliteli bir deneyim sunma zorunluluğuna işaret etmektedir. Bu bağlamda ziyaretçilere güvenli sanal ortam ve tatmin edici site deneyimi olmazsa olmaz olarak kabul edilmektedir. Sosyal medya araştırmalarında ziyaretçilerin korunması ilkesi ise resmî sosyal medya hesaplarına yönelik yönlendirmeler ve takipçi sayılarındaki değișimler ile 
belirlenmektedir. Bu noktadan hareketle araştırmaya konu olan markaların ziyaretçilerin korunması ilkesine yönelik bulguları Tablo 7'de özetlenmektedir.

Tablo 7: Ziyaretçilerin Korunması İlkesine İlişkin Bulgular

\begin{tabular}{|l|c|c|c|}
\hline & 1 Ekim 2019 Takipçi Sayısı & 1 Aralık 2019 Takipçi Sayısı & $\begin{array}{c}\text { Web Sayfasında Sosyal } \\
\text { Medya Hesap Linkleri }\end{array}$ \\
\hline Netflix & 61.893 .114 & 61.894 .381 & + \\
\hline Madame C. & 1.589 .157 & 1.618 .054 & + \\
\hline THY & 10.486 .949 & 10.658 .589 & + \\
\hline Ziraat B. & 2.138 .884 & 2.158 .992 & + \\
\hline Mutlu A. & 343.011 & 343.239 & + \\
\hline
\end{tabular}

Tablo 7'den anlaşılabileceği gibi araştırmaya konu olan markaların resmî web sitelerinde markalara ait tüm resmî sosyal medya hesaplarına ait linklerin yer aldığı belirlenmiștir. Markaların resmî sosyal medya hesaplarına kolayca web siteleri üzerinden güvenli bir şekilde ulaşılabilmektedir. Bununla birlikte markaların aynı şekilde sosyal medya hesaplarında resmî web sitelerinin linklerini paylaştıkları görülmüştür. Söz konusu durum, sosyal medya kullanıcılarının gayri resmî hesaplara yönlenmelerine karşı koruyucu bir önlem olarak değerlendirilebilmektedir.

Markaların 1 Ekim 2019-1 Aralık 2019 tarihleri arasında ortaya çıkan takipçi sayıları incelendiğinde ise araştırmaya konu olan tüm markaların iki aylık süre içerisinde takipçi sayılarını muhafaza etmekle kalmayıp artırdıkları saptanmıştır. Söz edilen bu durum, araştırmaya konu olan markaların Facebook sayfaları üzerinden takipçilerine kaliteli bir deneyim sunduklarına ișaret etmektedir. Tablo 8'de aktarılan veriler ışığında tüm markaların, diyalojik iletişim ilkelerinin beşincisi ve sonuncusu olan ziyaretçilerin korunması ilkesini yerine getirdikleri görülebilmektedir.

Tablo 8: Markaların Facebook Sayfalarında Görülen Diyalojik İlkeler

\begin{tabular}{|l|c|c|c|c|}
\hline & Diyalojik döngü & $\begin{array}{c}\text { Enformasyon } \\
\text { kullanışılığı }\end{array}$ & $\begin{array}{c}\text { Yeniden ziyaret } \\
\text { sağlama }\end{array}$ & $\begin{array}{c}\text { Ziyaretçilerin } \\
\text { korunması }\end{array}$ \\
\hline Netflix & & & + & + \\
\hline Madame C. & & + & + & + \\
\hline THY & + & + & + & + \\
\hline Ziraat B. & + & & + & + \\
\hline Mutlu A. & + & & + & + \\
\hline
\end{tabular}

Tablo 8'e göre araștırma kapsamındaki markaların Kent ve Taylor'ın hangi diyalojik ilkelerini karşıladıklarına bakıldığında ilk ilke olan diyalojik döngünün THY, Ziraat Bankası ve Mutlu Akü olmak üzere beş markadan sadece üçü tarafından karşılandığı görülmektedir. Söz konusu üç markanın Facebook sayfalarında takipçileri ile diyalog kurmaktan kaçınmadıkları gözlemlenmiştir. İkinci diyalojik ilke olan ve ticari amaç gütmeyen faydalı içerikleri ifade eden enformasyon kullanışlılığı ilkesinin, THY ve Ziraat Bankası'nın az sayıda da olsa Facebook sayfalarında ortaya çıktığı saptanmıştır. Araştırmanın analiz birimleri arasında yer alan yeniden ziyaret sağlama ve ziyaretçilerin korunması ilkelerinin ise araştırmaya konu olan tüm markaların Facebook sayfalarında ortaya çıktığı belirlenmiștir.

\section{Sonuç}

Araştırma bulguları, araştırmaya konu olan markaların Facebook sayfalarında diyalojik iletişim ilkelerinden en çok yeniden ziyaret sağlama ve ziyaretçilerin korunması 
ilkelerinin karşılandığını göstermektedir. Söz konusu ilkeler, araştırmaya konu olan tüm markaların Facebook sayfalarında bariz bir biçimde kendini göstermektedir. Bununla birlikte en az ortaya çıkan diyalojik ilke ise enformasyon kullanışlılığı olarak belirlenmiştir. Enformasyon kullanışlılığı ilkesi sadece THY ve Ziraat Bankası'nın üç paylaşımında ortaya çlkmıştır. Diyalojik ilkelerin ilki ve en önemlisi olarak kabul edilen diyalojik döngü ilkesinin ise THY, Ziraat Bankası ve Mutlu Akü olmak üzere üç markanın Facebook sayfasında sınırlı bir şekilde de olsa ortaya çıktığı saptanmıştır. Diğer iki marka Netflix ve Madame Coco'nun ise Facebook sayfalarında diyaloğun söz konusu olmadığı ve tek yönlü iletişimin ortaya çıktığı saptanmıştır. Diyalojik döngü ilkesi bir kuruluşun iletişime açık olup olmadığını göstermektedir. Bu noktadan hareketle edinilen bulgular ışığında, Netflix ve Madame Coco'nun Facebook sayfaları üzerinden iletişime açık olmadıkları çıkarımında bulunmak mümkündür. Bu durumun, bir marka stratejisi olduğunu düşünmek olasıdır. $\mathrm{Bu}$ süreçte her iki markanın, Facebook hesaplarını sadece ürün ve hizmet tanıtımı amacıyla tek yönlü iletişim ortaya çıkaracak şekilde aktif olarak kullandığı düşünülebilir. Ancak çalışmanın genelinde vurgulandığı üzere böylesi bir yaklaşımın, diyalojik iletişim ilkeleriyle bağdaşmadığını söylemek mümkündür. Sosyal medya hesapları pazarlama aracı olarak görülse bile, bu kanalların da diyoloğa dayalı biçimde kullanılması, marka iletişimi için gerekli görülmektedir.

Diyalojik iletişim ilkeleri geleneksel web sitelerinin ilişki geliştirme kapasitesini belirlemek amacıyla ortaya atılmış olmasına karşın ilk ilke olan diyalojik döngüye ayrı bir önem atfetmektedir. Bu teori, doğası gereği interaktif bir yapıya sahip olan sosyal medyaya uyarlandığında ise diyalojik döngü ilkesi çok daha fazla önem taşımaktadır. Diyalog geliştirmek üzerine yapılandırılmıș interaktif platformlarda sürdürülen marka faaliyetlerinin diyaloğa dayanmaması, söz konusu faaliyetleri baştan etkisiz kılabilmekte ve hatta zarar sağlayabilmektedir. Özellikle bu araştırmaya konu olan Facebook gibi eş zamanlı olarak son derece yüksek kalitede yazılı, görüntülü ve sesli iletişime olanak sağlayan bir platformun, markalar tarafından tek yönlü iletişim aracı olarak kullanılması, markanın sosyal medyadaki varlığını anlamsız kılmaktadır. Bu bağlamda Wilcox (2018), kurumsal iletişim uzmanları üzerine gerçekleştirdiği araştırmasında, kuruluş ve hedef kitlesi arasında karşılıklı fayda sağlayabilmek adına sanal ortamlarda mutlaka diyalojik ilkelerin karşılanması gerektiği bulgusunun öne çıktığını belirtmiştir. Bu kapsamda Netflix ve Madame Coco'ya yönelik elde edilen bulgu, Wilcox'un (2018) çalışması ile zitlık sergilemektedir.

Diyalojik iletişim teorisi bağlamında sosyal medyaya uyarlanarak yapılan araștırmalar, sayıca henüz çok olmasa da farklı sonuçlar ortaya koyma potansiyeli açısından dikkat çekmektedir. Bu bağlamda dünyadaki büyük prestijli müzelerin Facebook hesapları üzerine yapılan bir araștırma, müzelerin Facebook hesaplarının diyalojik ilkeleri karşılama bakımından yetersiz kaldığını ortaya koymuştur (Capriotti, 2018: 647). Bu durumun nedeni, müzelerin tam anlamıyla ticari kuruluş kaygısı gütmediği için diyalojik ilkeleri sağlamada yetersiz kalması ile açıklanabilir. Buna karşın ABD'de üniversitelerin sağlık birimlerinin sosyal medya hesapları üzerine yapılan bir araștırma, söz konusu birimlerin Facebook hesaplarının başta diyalojik döngü ve enformasyon kullanışlılığı olmak üzere tüm diyalojik iletişim ilkelerini karşıladığını açığa çıkarmıștır (Waters vd. 2011, s. 22). Bu bulgulardan hareketle Waters vd. (2011), iletişime açık olan ilgili birimlerin öğrenciler ile iyi ilişkiler kurup onlara faydalı içerikler sunduğunu saptamıştır. Benzeri bir bulgu, Gazi Üniversitesi'nin Twitter hesabına yönelik bir araștırmada da ortaya çıkmış ve iletişime açık yapının kurum ile öğrencilere sağladığı faydanın altı çizilmiştir 
(Can, 2017, s. 9-10). Söz konusu iki araştırma, ABD ve Türkiye'deki iki üniversitenin sosyal medya hesaplarında benzeri sonuçlar ortaya koymuş ve her iki eğitim kurumunun da sosyal medya hesaplarını doğru şekilde kullandığını gözler önüne sermiştir. Toledano ve Lalueza'nın (2018) gerçekleştirmiş olduğu araştırma da ABD’li işletmelerin sosyal medya hesaplarında, İspanyol işletmelere göre diyalojik ilkeleri daha başarılı uyguladığı ve diyalojik döngünün, ABD'li kuruluşların sosyal medya hesaplarında bariz bir biçimde görüldüğü saptanmıştır. Çetintaş (2019) tarafından İstanbul Sanayi Odası listesinde yer alan işletmelere yönelik yapılan araștırmada, Toledano ve Lalueza'nın (2018) verilerine benzer bulguların paylaşıldığı görülmüştür. Buna göre Çetintaş (2019), Türkiye'deki işletmelerin sosyal medyanın ilişki geliștirme kapasitesini henüz kavrayamadıklarını ortaya koymuştur. Bu çalışmaya konu olan araştırma da Çetintaş'ın (2019) çalışmasındaki bulguları doğrular niteliktedir. Nitekim incelenen markalarda, diyalojik ilkelerin tam anlamıyla işlerlik kazandığını söylemek mümkün değildir. Elde edilen sonuca rağmen beş markadan üçünde tüm diyalojik ilkeler ortaya çımasa bile diyalojik döngünün görülmesi, Türkiye'de faaliyet gösteren kuruluşların sosyal medya kullanımı açısından ileriki dönemler için umut verici bir gelişme olarak yorumlanabilmektedir. Ancak yine de gerçekleștirilen araştırma bağlamında, Türkiye'deki markaların sosyal medya hesaplarında diyalojik iletişime daha çok önem vermeleri ve başta diyalojik döngü olmak üzere, diyalojik iletişimi oluşturan ilkelerin hepsine daha çok eğilmeleri gerektiği açıkça kendini göstermektedir.

Diyalojik iletişim teorisinin dayandığı diyalojik prensiplerin kuruluşların web siteleri ve sosyal medya hesaplarında ortaya çıkmasının hem kuruluş hem de hedef kitlelerine fayda sağlayacağı kabul edilmektedir. Söz konusu karşılıklı fayda ise diyalog ve iyi ilişkiler üzerine kurulmaktadır. Bu noktada zaman ve mekân sınırlaması olmayan ve interaktif yapısı ile sosyal medya, tüm kurum ve kuruluşlara büyük fırsatlar sunmaktadır. Söz konusu fırsatların gün geçtikçe kurum ve kuruluşlar tarafından daha iyi anlaşıldığı düşünülse de diyalog geliştirme konusunda yaşanan ve halen mevcut olduğu görülen eksiklikler, bu konunun öneminin tam olarak kavranamadığına işaret etmektedir. $\mathrm{Bu}$ bağlamda çalışmanın ilerleyen yıllarda tekrar edilmesi durumunda çok daha farklı bulguların ortaya çıkması muhtemeldir.

\section{Kaynakça}

Abdüsselam, M. S., Burnaz, E., Ayyıldız, H., ve Demir, İ. (2015). “Web Teknolojilerinin E-Ticaret Ortamlarında Kullanımı İle İlgili İçerik Analizi: Türkiye'deki İlk 500 ETicaret Sitesi". Karadeniz Teknik Üniversitesi Sosyal Bilimler Enstitüsü Sosyal Bilimler Dergisi (10):263-84.

Akar, E. (2011). Sosyal Medya Pazarlaması, Sosyal Web'te Pazarlama Stratejileri. 2. bs. İstanbul: Elif Yayınları.

Akbar, S., ve Özgül, E. (2018). “Impact of Social Media Usage Activities on Brand Awareness of Young Consumers”. Dokuz Eylül Üniversitesi İktisadi ve İdari Bilimler Fakültesi Dergisi 33(1):217-30.

Ali, M., Iraki, K., Khan, L., ve Salam, F. (2019). “The Effect of Traditional Media Communication and Social Media Communication in Generating Consumer Based Brand Equity in Context of Pakistan". South Asian Journal of Management Sciences 13(2):32-54.

Angeline, M., Chandra, S., Kinanti, F., Singgih, Y., ve Safitri, Y. (2019). “Digitalize Your Brand: Case Study on How Brands Utilize Social Media Platforms to Achieve Branding and Marketing Goals". Ss. 278-83 içinde. Jakarta \& Bali. 
Anonim. (2019). "Number of Monthly Active Twitter Users Worldwide from 1st Quarter 2010 to 1st Quarter 2019”. Statista. Geliş tarihi 26 Nisan 2020 (https://www. statista.com/statistics/282087/number-of-monthly-active-twitter-users/).

Aytan, C., ve Telci, E. (2014). "Markaların Sosyal Medya Kullanımının Tüketici Davranışları Üzerindeki Etkileri”. TOJDAC 4(4):1-15.

Baş, T., ve Akturan, U. (2008). Nitel Araştırma Yöntemleri. 2. bs. Ankara: Seçkin Yayınları.

Başaran, Y. K. (t.y.) “Sosyal Bilimlerde Örnekleme Kuramı”. Akademik Sosyal Araştırmalar Dergisi 5(47):480-95.

Başkale, H. (2016). "Araştırmalarda Geçerlilik Güvenirlilik ve Örneklem Büyüklügünün Belirlenmesi". DEUHFED 9(1).

Can, S. (t.y.) "Diyalojik İletişim Gözüyle Gazi Üniversitesi Twitter Hesabına Bir Bakıș”. Ss. 1-11 içinde. Ankara: SOSBÍLKO.

Capriotti, P., ve Diaz, C. L. (2018). "Facebook As Dialogic Communication Tool At The Most Visited Museums Of The World”. El profesional de la información 27(3).

Christensen, L., Johnson, R. B., ve Turner, L. A. (2015). Araştırma Yöntemleri Desen ve Analiz. 2. bs. Ankara: Anı Yayıncılık.

Creswell, J. W. (2019). Karma Yöntem Araştırmalarına Giriş. 2. bs. Ankara: Pagem Akademi.

Çetintaş, H. B. (2019). "Diyalojik Paydaș İletişimi İçin Twitter Kullanımı". Anadolu Üniversitesi Sosyal Bilimler Dergisi 19(3):83-96.

Değerli, A. (2016). “Ağ Toplumunun İletişimi Ekseninde Yerel Yönetimlerin Sosyal Medya Kullanım Düzeyi: Kadıköy Belediyesi Örneği". Marmara Üniversitesi Öneri Dergisi 12(46):63-79.

Demirli, C., ve Kütük, Ö. F. (2016). "Anlamsal Web (Web 3.0) ve Ontolojilerine Genel Bir Bakış”. İstanbul Ticaret Üniversitesi Fen Bilimleri Dergisi 12(46):95-105.

Erdoğan, İ. (2007). Pozitivist Metodoloji-Bilimsel Araştırma Tasarımı İstatiksel Yöntemler Analiz ve Yorum. 2. bs. Ankara: Erk Yayınları.

Gao, H., Tate, M., Zhang, H., Chen, S., ve Liang, B. (2018). "Social Media Ties Strategy in International Branding: An Application of Resource-Based Theory". Journal of International Marketing 26(3):45-69.

Gliner, A., Morgan, G. A., ve Leech, M. L. (2015). Uygulamada Araştırma Yöntemleri Desen Analizi ve Bütünleştiren Yaklaşım. İstanbul: Nobel Yayıncılık.

Güçlü, İ. (2019). Sosyal Bilimlerde Nitel Araştırma Yöntemleri Teknik, Yaklaşım ve Uygulama. İstanbul: Nobel Yayıncılık.

Jakštė, L., Ostreika, A., Jakštas, A., Jakštas, E., ve Damaševičius, R. (2017). "Brand Communication in Social Media: The Use of Image Colours in Popular Posts". Ss. 1373-78 içinde. Opatija, Croatia.

Jarreau, P. B., ve Porter, L. (2018). "Science in the Social Media Age: Profiles of Science Blog Readers". Journalism \& Mass Communication Quarterly 95(1):142-68.

Kawamoto, Y., Nishiyama, Y., Kobayashi, A., Sakaji, H., ve Masuyama, S. (2016). “Investigation and Construction of Dictionary for Analysis of Comments in a Video Sharing Site". Ss. 1-6 içinde. George Town, Malaysia, 16-19 Aug.: ICAICTA. 
Kent, M. L., ve Taylor, M. (1998). “Building Dialogic Relationships Through the World Wide Web". Public Relations Review 24(3):321-34.

Kent, M. L., ve Taylor, M. (2002). “Toward a Dialogic Theory of Public Relations”. Public Relations Review (28):21-37.

Kim, M., Moon, S., ve Lacobucci, D. (2019). "The Influence of Global Brand Distribution on Brand Popularity on Social Media". Journal of International Marketing 27(4):22-38.

Koçoğlu, E. (2019). "Sosyal Ağların Sosyal Bilgilerde Kullanılmasına İlişkin Öğretmen Alglları". Avrasya Sosyal ve Ekonomi AraĢtırmaları Dergisi 6(3):261-73.

Kupfer, A. K., Holte, N. P., Kübler, R. V., ve Thurau, T. H. (2018). “Brand's Social Media Power in Brand Alliances". Journal of Marketing (82):24-45.

Miles, M. B., ve Huberman, A. M. (1994). An Expanded Sourcebook: Qualitative Data Analysis. 2. bs. NY: Sage Publications.

Monteiro, C. D. D., Shipman, F., ve Gutierrez-Osuna, R. (2018). "Comparing Visual, Textual, and Multimodal Features for Detecting Sign Language in Video Sharing Sites". Ss. 7-12 içinde. Miami, Florida, USA, April 10-12: IEEE.

Naik, U., ve Shivalingaiah, D. (t.y.) “Comporative Study of Web 1.0, Web 2.0 and Web 3.0." Ss. 1-12 içinde. Allahabad: CALIBER.

Neuman, W. L. (2019). Toplumsal Araştırma Yöntemleri Nitel ve Nicel Yaklaşımlar, (Çev: S. Özge). 3. bs. İstanbul: Yayın Odası Yayınları.

Okmeydan, C. K. (2019). “Diyalojik İletişimin Sosyal Müşteri İlişkileri Yönetimine Katkısı: Kurumsal Markalar Üzerine Bir Araștırma”. Doktora Tezi, Ege Üniversitesi Sosyal Bilimler Enstitüsü, İzmir.

Okmeydan, S. B. (2018). "Siyasal Halkla İlişkiler ve Siyasi Partilerin Sosyal Medya Kullanımı: 24 Haziran 2018 Seçimleri Üzerine Bir Araştırma”. Ss. 139-61 içinde. Aydın: Adnan Menderes Üniversitesi.

Özdemir, B. P., ve Yamanoğlu, M. A. (t.y.) "Türkiyedeki Sivil Toplum Kuruluşları Web Sitelerinin Diyalojik İletișim Kapasiteleri Üzerine Bir İnceleme”. Ankara Üniversitesi Sosyal Bilimler Enstitüsü Dergisi 1(2):3-36.

Özoran, B. A. (t.y.) "Bir Halkla İlişkiler Ütopyası: Diyalojik Halkla İlişkiler". İstanbul Üniversitesi İletişim Fakültesi Dergisi (53):1-30.

Pitt, C. S., Plangger, K. A., Botha, E., Kietzmann, J., ve Pitt, L. (2019). "How Employees Engage with B2B Brands on Social Media: Word Choice and Verbal Tone". Industrial Marketing Management (81):130-137.

Sánchez-Villar, J. M. (2018). "The use of blogs as social media tools of political communication: citizen journalism and public opinion 2.0." 32(1):39-55.

Schöps, J. D., Wegerer, P. K., ve Hemetsberger, A. (2017). "Brand-Mediated Ideological Edgework: Negotiating the Aestheticized Human Body on Instagram - The Case of American Apparel". Advances in Consumer Research 45(1):474-78.

Sharma, S., ve Godiyal, S. (2016). "A Study on the Social Networking Sites Usage by Undergraduate Studen". Online International Interdisciplinary Research Journal 6(3):157-63. 
Sönmez, S., ve İlgün, G. (2018). "Nitel Araştırma Yöntemlerinin Sağlık Hizmetleri Bağlamında İncelenmesi”. Balıkesir Üniversitesi Sosyal Bilimler Enstitüsü Dergisi 21(40):375-99.

Şengöz, A., ve Eroğlu, E. (2017). "Örgütlerde Sosyal Medya Kullanımı: Sosyal Medya Algıları,Amaçları ve Kullanım Alışkanlıkları”. Gümüşhane Üniversitesi İletişim Fakültesi Elektronik Dergisi 5(1):503-24.

Tadesse, M. M., Lin, H., Xu, B., ve Yang, A. L. (2019). “Detection of Depression-Related Posts in Reddit Social Media Forum". IEEE Access 7(1).

Toledano, C. A., ve Lalueza, F. (2018). "Monologues In The Conversational Era: Assesing The Level Of Dialogic Communication That Big Firms Are Reaching On Social Media". El profesional de la información 7(6):1270-80.

Topa Çiftçi, G. (2017). "Hizmet İçi Eğitim Bağlamında Yapllan İletişim Eğitimlerinde Alternatif Bir Yöntem Olarak Yeni Medya Platformlarından Blog Kullanımı”. Akdeniz Üniversitesi Sosyal Bilimler Enstitüsü Dergisi 1(2):39-61.

Uztuğ, F. (2002). Markan Kadar Konuş: Marka İletişim Stratejileri. İstanbul: MediaCat Kitapları.

Wang, X. U., Cao, Y. M., ve Park, C. (2019). “The Relationships Among Community Experience, Community Commitment, Brand Attitude, and Purchase Intention in Social Media". International Journal of Information Management (49):475-488.

Waters, R., Canfield, R. R., Foster, J. M., ve Hardy, E. E. (2011). "Applying the Dialogical Theory to Social Networking Sites-Examining How University Health Centers Convey Health Message on Fecebook". Journal of Social Marketing 1(3):211-57.

Whittaker, Z. (2008). "Web 3.0 The Future of Social Networking”. ZD Net. Geliş tarihi 13 Ekim 2019 (https://www.zdnet.com/article/web-3-0-the-future-of-social-networking).

Wilcox, D. L. (2018). "Dialogic Communication Theory in the Age of Corporate Activism: A Postmodern Perspective". Communication and Media in Asia Pasific 2(1):1-10.

Yağmurlu, A. (2013). "Diyalojik İletişim Çerçevesinden Ankara Büyük Şehir Belediyesi Sosyal Medya Uygulamaları". Selçuk İletişim 8(1):5-15.

Yıldırım, S., Jothimani, D., Kavaklığlu, C., ve Başar, A. (2019). “Deep Learning Approaches for Sentiment Analysis on Financial Microblog Dataset”. Ss. 5581-84 içinde. Los Angeles, USA, December 9-12: IEEE.

Yüce, A., ve Tașdemir, N. H. (2019.) "Kurumsal İtibarı Sağlamada Sosyal Medyanın Etkin Rolü: Kurumsal İtibar Lideri Firmaların Sosyal Medya Paylaşımlarının İncelenmesi". Uluslararası Sosyal Araştırmalar Dergisi 12(63):1185-96. 


\title{
The Most Active Brands of the Social Media: A Research on Facebook within the Context of Dialogical Communication Theory
}

\author{
Cudi Kaan Okmeydan (Res. Asst. Ph.D.)
}

\section{Extended Abstract}

This study focuses on determining the dialogic communication loops of the top five brands in the following order Netflix, Madame Coco, THY, Ziraat Bankası ve Mutlu Akü, which are the brands that use Facebook the most actively according to September 2019 Report of Boom Social. In order to discover the Dialogic Communication Loop, the Dialogic Theory, developed by Kent and Taylor (1998) for measuring the relation establishment capacities of websites, is used. The theory is configured on the benefit to be provided to the source and the receiver by the dialogue and relation established between the institution and target group (Değerli, 2016, p.66). The Dialogic Communication Theory is based on five dialogic principles. The first principle, which is considered as the most important one, is the "Dialogic Loop", The Dialogic loop determines whether the institution is open to communication or not, and explains the feedback loop between the target groups and the organizations (Kent and Taylor, 1998, p. 326-327). The other principles are: "Usefulness of Information", which implies the presentation of useful content, "Generation of Return Visits", which encourages frequent visits to the websites, "Ease of Interface", which means the easiness of use of the website, and "Conservation of Visitors", which implies the presence of a high quality experience of the website.

The official Facebook pages of the brands mentioned above have been reviewed by the content analysis method within the context of Dialogic Communication Principles of Kent and Taylor. The documents to undergo the content analysis can be assembled on the electronic data. Thus an extensive range of data including e-mails, e-groups, web pages, blogs, and so on can be used as data collection tools (Baş and Akturan 2008, p. 119). The obtained data is limited with the shares of the five brands mentioned above on their official Facebook pages within $1^{\text {st }}$ October- $1^{\text {st }}$ December 2019 . The data is obtained by the quantitative content analysis method in examination of the official Facebook pages of the five brands described above that are selected according to the purposeful sampling method. Purposeful sampling signifies the examination of the units conforming to the purpose, which are defined and determined initially (Erdoğan, 2007, p. 176). That sampling method, which does not include the probability base, enables to examine and research in-depth the cases containing rich information concerning the objective of the research (Başaran, 2017, p. 490). However, to reach the data saturation is essential and more important than the sampling size (Creswell, 2019, p. 82). In this study, the dialogical communication levels of the official Facebook pages of the five brands included in the sampling group have been attempted to be explained based on the dialogic principles of Kent and Taylor (1998).

In light of the findings obtained by adaptation of the models in the related researches, it has been determined that the dialogic loop, which is the first one of the dialogical communication principles of Kent and Taylor, does not occur on the Facebook pages of Netflix and Madame Coco. These two are the brands using Facebook in the best way 
according to the "Social Brands Report" of Boom Social in September 2019. On the other hand, long dialogues between the brand and the followers have been observed on the Facebook pages of THY, which is in the third order of the list, Ziraat Bankası, which is in the fourth order, and Mutlu Akü, which is in the fifth order. The dialogic loop principle occurred on these pages. The occurrence of the dialogic loop, which is the first and the most important of the dialogic communication principles, on the Facebook pages of THY, Ziraat Bankası, and Mutlu Akü reveals the openness of those brands to communication and the interaction power generated by the shared contents. On the Facebook pages of the other two brands. Netflix and Madame Coco, it has been found that dialogue is not the point in question, and the unilateral communication is employed. From this point forth, it is possible to conclude that Netflix and Madame Coco are not open to communication. According to this research based on the content analysis, which has been performed within the context of the dialogic communication principles of Kent and Taylor, it is possible to say that the principal difference between the brands included in this research stems from the principle of "dialogic loop".

When the contents of the shares of the brands included in the research are reviewed, it has been observed that the number of informative and non-commercial shares is meager. This fact signifies that the usefulness of information principle is not in question in the case of the Facebook pages of the brands included in the research. On the other hand, it has been observed that the Facebook pages of all the brands are extremely updated and employ mostly visual shares such as videos and photographs. That finding reveals that all the brands have observed the Generation of Return Visits principle. Ease of Interface, which is the fourth principle, has not been taken into account because Facebook has got a standard interface. The fifth and last principle of "conservation of visitors" manifests itself by sharing the connection buttons of official social media accounts on the institutional web pages of the brands, including the connection addresses of the institutional websites on the Facebook pages and increase in the number of the followers within two month research period. It is seen that in the research conducted, mostly the principles of generation of return visits and conservation of visitors, which are included in the dialogic communication principles, have been observed on the Facebook pages of the brands. The said principles have been observed demonstrably on the Facebook pages of all the brands included in the research. Also, it has been found that the principle of the usefulness of information is the principle that occurs the least, whereas the principle usefulness of information has occurred only in three shares of THY and Ziraat Bankası.

Keywords: Public Relations, Web, Social Media, Communication, Dialogical Communication. 